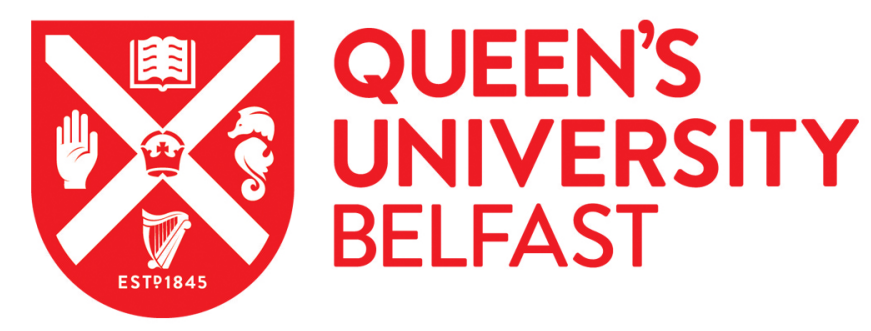

\title{
Leveraging Nordic links: South African labour's role in regulating labour standards in wine global production networks
}

Hastings, T. (2019). Leveraging Nordic links: South African labour's role in regulating labour standards in wine global production networks. Journal of Economic Geography, 19(4), 921-942. https://doi.org/10.1093/jeg/lbz010, https://doi.org/10.1093/jeg/lbz010

Published in:

Journal of Economic Geography

Document Version:

Peer reviewed version

Queen's University Belfast - Research Portal:

Link to publication record in Queen's University Belfast Research Portal

Publisher rights

Copyright 2019 Oxford University Press. This work is made available online in accordance with the publisher's policies. Please refer to any applicable terms of use of the publisher.

\section{General rights}

Copyright for the publications made accessible via the Queen's University Belfast Research Portal is retained by the author(s) and / or other copyright owners and it is a condition of accessing these publications that users recognise and abide by the legal requirements associated with these rights.

Take down policy

The Research Portal is Queen's institutional repository that provides access to Queen's research output. Every effort has been made to ensure that content in the Research Portal does not infringe any person's rights, or applicable UK laws. If you discover content in the Research Portal that you believe breaches copyright or violates any law, please contact openaccess@qub.ac.uk. 


\section{Introduction}

In recent years more attention has been placed on the role of labour and the state in the governance of global production networks (GPNs; Alford and Phillips, 2018; Barrientos, 2013; Barrientos et al. 2011; Newsome et al., 2015; Horner, 2017; Riisgaard and Hammer, 2011). Key to this development has been recognition of labour's agency in campaigning for labour process change and the stronger regulation of supply chains, including a role for workers in the mediation of codes of conduct and private standards intended to improve work conditions on the ground (Lund-Thomsen and Coe, 2015; Nadvi, 2008). Relevant in this discussion has been the rise of multi-stakeholder initiatives (MSIs) involving a role for both labour and capital stakeholders in determining private standards for firms to adhere to. Often linked to Corporate Social Responsibility (CSR) agendas of lead firms within supply chains, a role for workers in the regulation of supply chains has proved especially appealing in the absence of effective state labour law enforcement in much of the Global South (Vogel, 2010).

Despite recognition for labour's regulatory capabilities (e.g. informing retailers or unions on violations of working practice; Lund-Thomsen and Lindgreen, 2014; Selwyn, 2013) less attention has been placed on labour's ability to challenge ineffectual monitoring of firm behaviour, including the subversion of worker rights and the fudging of private codes/standards across spatially stretched supply chains. Spurred by the capitalist imperative to maximise profits, critics have underlined the structural realities of labour market exploitation in which firms 'thwart, neutralise or trump interventions ostensibly designed to improve conditions, such as codes of practice, multilateral initiatives (ILO and OECD guidelines) or government legislation' (Taylor et al. 2015: 12). Building on the increasing focus on labour's agency in the theorising of GPNs, the paper explores proactive, networked interventions by labour groups intent on altering the monitoring and enforcement of private standards in the case of South African wine (Büthe and Mattli, 2011). Through this focus the paper contributes to more 'radical' approaches in the theorising of GPN frameworks which are currently emerging. 
Two main contributions are offered. Firstly, the paper demonstrates the relevance of labour's networked agency in GPN extra-firm regulation, illustrating how worker groups at the local level in South Africa have forged international networks to help expose and address conditions at the farming level of wine supply chains. Secondly, building on this point, the paper explores the efficacy of labour's collective agency in stimulating different actors (firms, private regulators and the state) to play a greater role in monitoring conditions at the farm level of wine supply chains, increasing the threat of sanction for firms which deny labour rights. Relational effects of labour's agency are shown to influence the regulatory approaches of a key private compliance initiative (PCI) in South African wine, The Wine Industry Ethical Trade Association (WIETA), encouraging more proximate/authoritative methods for tackling labour standards non-compliance. The research draws on fieldwork conducted globally between 2014 and 2018, as linked to a wider project examining national labour policies and approaches to labour inspection (this incorporated a total of fifty-nine interviews with officials involved in public administration and state/third party regulation in different regions of the world). Four trips to South Africa facilitated twenty-three interviews with private auditors, labour inspectors, trade unions, employer associations and Non-Government Organisations (NGOs), in addition to a focus group with South African labour inspectors ${ }^{1}$.

The paper proceeds as follows. The next section provides an overview of ongoing debates surrounding the (changing) analytical value of GPN frameworks in understanding worker praxis. This is followed by discussion of the South African case study context. The main discussion is then used to explicate a role for GPN frameworks in exploring labour's own strategies for improving conditions at firm level and beyond (i.e. local labour control regimes; Hastings and MacKinnon, 2017; Taylor et al., 2015). A conclusion summarises the main contributions and encourages future steps.

\section{GPNs, labour control and labour standards}

As part of a more 'radical' take on Global Production Networks (GPNs), recent studies have called for extended uses of the GPN framework in line with its initial open and relational ontology (Coe et al. 
2004; Coe et al. 2008; Henderson et al. 2002; Yeung and Coe, 2015). The genesis of the GPN framework can be traced to Peter Dicken's seminal work (notably initial versions of Global Shift) which theorised global business dynamics from a spatial perspective (Dicken, 1986), although the framework has always held the potential to aid wider explorations of the global political economy. Noting this point, Cumbers (2015), has encouraged an expanded take on the GPN framework, arguing that the model could/should also be geared to broader explanatory projects exploring networked relationships between local places and actors across the global economy. Accordingly:

'The GPN framework in its initial conception adds value to our understanding precisely because it combines a relational perspective on the way local places and actors are embedded in broader global networks whilst integrating a sense of the continuing importance of vertical territorial relations, such as the role of states and local labour control regimes...in shaping economic and social outcomes' (Cumbers 2015: 136).

The paper builds on this call to extend the use of GPNs with a view to showing how the networked agency of workers can generate relational pressures on capital: i.e. 'the way that the actions of workers in one place can have impacts on those in another location within a GPN' (ibid.). The contribution adds to a now fulsome body of work theorising the role of labour and worker agency in influencing GPNs (Barrientos et al. 2011; Carswell and De Neve, 2013; Coe, 2012; Coe et al. 2008; Coe and Hess, 2013; McGrath 2013; Rainnie et al. 2011; Selwyn 2013; Wad 2013). Specifically, it focuses on labour impacts on private and public governance integral to territorial relations and local labour control regimes (see Bartley 2018). By local labour control regimes (local LCRs), I draw on Jonas' definition of a stable local institutional framework for accumulation and labour regulation constructed around local labour market reciprocities (Hastings and MacKinnon, 2017; Jonas, 1996; Kelly, 2013). In doing so, the paper shows how productive tensions between places and networks impact upon production sites and local LCR arrangements including the terms under which producers are monitored within globally integrated supply chains/production networks. 
Work in the Power Resources Approach (PRA) is instructive in this context for examining different forms and strategies of power of use in contesting structural constraints and exploitation in the workplace (Bieler 2018; Birelma 2018; Schmalz et al. 2018; Schmalz et al. 2019). Early work in this vein, notably by Wright (2000) and Silver (2003), proved key in distinguishing associational forms of power as that derived from collective organisation (e.g. unions, parties), by contrast to structural power based on labour's position in a production process (e.g. ability to disrupt production by striking at a key point in a supply chain; Cumbers 2015; Silver 2003; Taylor et al. 2015; Wright 2000). Research using the PRA has elaborated on the links between these and other labour organising strategies, including a more recent focus on symbolic and institutional forms of power. Drawing on Bourdieu (2000: 185-186), Chun presents symbolic power as a 'politics of perception aimed at making or subverting the order of things by transforming or conserving the categories through which it is perceived' (Chun 2009: 13). Across divergent cases from the U.S. and South Korea (e.g. outsourced service work including the status of janitors), the leverage of symbolic power is shown through the use of public 'dramas'/displays (e.g. protest banners, the occupation of public spaces) which stimulate moral concerns and debate over concepts of 'justice' and 'fairness' in society. This focus on public drama is illustrative of the role of media in carrying messages of injustice to wider audiences, leveraging pressure to improve conditions in different labour market contexts. Similarly, recent work by Bank Muñoz (2018) on Walmart workers in Chile has stressed the linked nature of structural and associational power in generating forms of social power (a term which broader incorporates different capacities for disruption).

Other relevant examples of labour's networked praxis include the case of transport workers' organising in Egypt, with Anderson (2013) showing how local worker groups were able to utilise inter/transnational support (notably from the International Transport Workers' Federation) to encourage new national political structures and legal organising permissions following the Arab Spring (Anderson, 2013; see also Wad 2013). Writing in the aforementioned conceptual piece Cumbers (2015) similarly discusses how labour groups in China were able to harness international exposure of conditions at Foxconn to press Chinese authorities to loosen union controls (i.e. in the interests of grassroots organisers; Silver 2003Likewise, Featherstone's focus on the process geographies of the Inter- 
Continental Caravan (a collaboration of grassroots activists opposed to bio-engineering) has shown how connections and complex antagonisms between different place-based movements have led to effective (different) responses to neo-liberal globalisation (Featherstone, 2008; 2012). As noted by Allen (2003: 55), 'global networks campaigning...represent(s) a form of social solidarity which transcends local, community notions of public space and can effectively turn such 'sites' into distanciated networks'. The outcome of these relational geographies (e.g. forged through connections between labour, civil society and other actors globally) can thus create social change in different spaces of the globe.

The key point here is labour's ability to connect local struggles relationally to other places/actors across space, creating platforms from which to challenge capital and capital 'friendly' rules/institutions which drive labour's exploitation on the ground (Cumbers 2015: 138; Cumbers et al. 2016). Building on these studies, the paper explores the agency of union/NGO activist groups in South Africa and their efforts to develop powers of association with likeminded actors elsewhere in the world economy (i.e. those relevant to South African wine GPNs). In particular, the article focuses on worker efforts to develop symbolic leverage as a means of stimulating alterations to private regulation of the wine industry in South Africa, focussing on efforts to adjust a leading private compliance initiative (PCI): The Wine Industry Ethical Trade Association (WIETA). Through this contribution I build on Peck's call to theorise worker actions in relational and contextual terms simultaneously with analysis of the restructuring of capital, the state and modes of labour-market governance (Peck, 2013: 112). This appreciation for contextual/relational outcomes is seen to offer a useful corrective to exaggerated accounts of worker agency within labour geography which emerged as part of a corrective to capitalcentric accounts of economic change (Coe and Jordhus-Lier, 2011; Herod, 2001). In this case, labour's agency is shown to mediate and transform relations between global processes (i.e. the use of private standards and approaches for applying these) and the regulation of local social relations on which production is based (Del Casino et al., 2000).

The rise of international standards and private regulation: what role for labour? 
Since the 1990s the rise of PCIs has coincided with the increased use of multi-stakeholder initiatives (MSIs) as a means encouraging ethical standards in GPNs (in particular in relation to labour and environmental standards adherence; Hughes, 2001; Hughes et al. 2013; LeBaron and Lister 2015; LundThomsen and Lindgreen, 2014; Nadvi, 2008; Ponte and Ewert, 2009; Ruwanpura, 2016). Based on collaborations between corporations and civil society organisation/NGOs, MSIs are typically reliant on the voluntarily adherence of firms to private codes/standards under a 'compliance based' approach to regulation (i.e. more typically based on use of 'soft laws' and techniques of advising and persuading through conciliation; Fransen, 2012; Fransen and Kolk, 2007; Mena and Palazzo 2012: 527; O'Rourke, 2006; Rasche, 2012). In this respect the UK's Ethical Trade Initiative (ETI) has been heralded as an effective MSI promoting opportunities for both labour and capital groups to negotiate relations and enhance conditions for workers in supply chains (Blowfield, 2002). Past research has produced a largely positive appraisal of the ETI inspired Wine Industry Ethical Trade Association (WIETA) considered in this discussion, observing WIETA's potential as a multi-stakeholder initiative (MSI) to encourage labour standards and educate wine producers in line with their ETI inspired codes (derived in large part from ILO conventions; see also Bek et al. 2007).

Nevertheless, critical discussion has pointed to a dominant role for business actors in developing and monitoring private standards, with reports noting a lack of transparency in accountability practices and the failure of MSIs to represent labour interests despite agreements to the contrary (see Dolan and Opondo, 2005; Fuchs et al. 2009). Related concerns have also featured in (largely positive) accounts of WIETA, where trade union and NGO frustrations include barriers to worker organising and a lack of worker voice despite MSI agreements (see McEwan and Bek, 2009). In this respect even positive perspectives on the capabilities of MSIs and compliance based approaches have questioned the real term benefits for workers, pointing to a common imbalance in power relations in the favour of capital and firm preferences for softer forms of regulation (Büthe and Mattli, 2011; Fransen, 2012; Fransen and Kolk, 2007; Locke et al. 2007; Lund-Thomsen, 2013; Nadvi, 2008)². Equally, research has tended to underplay the associational powers of worker groups which stretch outside the formal confines of MSI boardrooms, connecting wider relational geographies which infuse global industries and their 
production networks. Writing ten years ago McEwan and Bek noted with enthusiasm the connections WIETA itself had helped forge between trade unions, grassroots movements, NGOs, producers, government departments, legislative bodies and international retailers, and the possibilities this opened up despite labour stakeholder frustrations (McEwan and Bek, 2009: 733). However, outside of dialogue with international retailers, stakeholder interactions were seen as largely internal to the South African context. This would seem to restrict the potential of workers to alter/adjust the politics and regulatory approaches of MSIs and their potential to improve working standards within GPNs.

Drawing on the relational ontology of GPNs, and extending past research on WIETA (Bek et al. 2007; McEwan and Bek, 2009), the paper casts light on the ability to workers to shape MSIs in more 'labour friendly' directions through transnational action. In doing so the paper challenges a view that MSIs are restricted to 'soft power' approaches to regulation favoured by capital. In making this point the paper draws on John Allen's understanding that power cannot be owned/possessed, and instead emerges from relations between groups and individuals (Allen, 2003; Herman, 2014: 1929). Depending on the outcome of interactions (i.e. those on MSI boards and/or further afield), alternative strategies for regulation may emerge encouraging new modalities of power. These modalities may be based on new expressions of influence, including forms of authority, manipulation, inducement and seduction, as well as more direct coercive techniques which influence outcomes (Allen, 2003). Crucially, they rely on different levels of proximity and placement to work effectively. Thus:

'Relationships of authority... work through proximity and presence if they are to be at all effective in drawing people into line on a day-to-day basis. The more direct the presence, the more intense the impact. The same holds for coercive relationships, that most visible imprint of power, where the threat of force lasts only for as long as people feel constrained by its possibility.' (Allen, 2004: 24)

More typically research into MSIs has noted a reliance on powers of persuasion (i.e. market access in exchange for standards accreditation), with more coercive methods residing in the hands of state labour inspectorates (who may fine or sanction firms for breaking laws; see Baldwin et al. 2012). Drawing on 
this understanding of power as a process subject to influence and change, the paper explores the relational effects of labour's networked agency and the possibility to effect new approaches of private (and to a lesser extent public) regulation. The rest of the paper is divided into three main sections. The following section discusses local labour control in the Western Cape wine industry and the rise in PCI/MSI governance models within this context.

\section{South African wine: the rise of globally integrated production networks}

In recent decades South Africa has strengthened its position as a key player within the highly globalized, international wine industry, operating as the sixth highest exporter of wine globally in terms of volume (approximately 4.5 million hectolitres exported annually; Aurand, 2018). Connected to global markets through a multitude of GPNs, the wine industry is an important income stream for the Western Cape in particular where the majority of South Africa's wine is produced, responsible for around 167,500 jobs in the region (53\% of GDP generated through wine was based in the Western Cape in 2013; Sawis, $2015)^{3}$. Within this context, connections to European markets have proved especially important, with South African wine accounting for around 14\% of all EU wine imports in 2017 (EuroStat 2018).

Due to climatic reasons a series of countries within Northern Europe are especially reliant on import arrangements for sourcing wine. This includes the Nordic countries (Denmark, Sweden, Norway, Finland, Iceland and the Faroe Islands) which spent approximately \$2.1 billion on wine imports in 2017 (UN Comtrade $2018^{4}$ ). Buoyed by especially strong sales to Sweden and Denmark, Nordic countries accounted for approximately 10.3\% of all South African wine exports in 2017 (author's calculations; ibid). In terms of their integration into wine GPNs, Sweden, Norway, Iceland and Finland are especially interesting due to their use of state-run alcohol monopoly retailers: the only high-street shops which can sell wine to the public in these countries. The alcohol monopolies (e.g. Systembolaget in Sweden, Vinmonopolet in Norway) operate with strict tender procedures and strongly regulate the quantity and quality of wine imports available. Faced with pressure to deliver to a high standard, these state retailers have developed a reputation for good service and responsible sourcing features which also render them especially sensitive to negative publicity of their supply chains (see Christopherson and Lillie, 2005; 
Örnberg and Ólafsdóttir, 2008). The following section contextualises this risk through a historical overview of labour control on wine farms in South Africa.

Labour control and South African wine: a history of exploitation within wine GPNs

Under apartheid the South African wine industry developed an indigenous form of strategic coupling in the Western Cape supported by state tariff protections and subsidies and the provision of a highly disciplined/affordable non-white workforce. This system helped spur the advancement of a series of lead firms, allowing for significant (though poorly distributed) value capture across the Western Cape (see Figure 1). Through the resulting spatial fix, production was secured through a series of punitive local labour control regimes based on the exploitation of vulnerable and historically disenfranchised worker groups.

\section{(Insert) Figure 1: Map of South Africa's Western Cape}

It is important to put this exploitation in socio-historical context. Wine and fruit industries in the Western Cape emerged during an era of master-slave relations which structured South African farm work under colonialism. Despite the abolition of slavery in 1834 , punitive work regimes were maintained on farms, with profound impacts on 'Coloured' workers in particular who tended to live on the farm under the full control of the farmer ${ }^{5}$. Male workers commonly worked on a permanent basis, while female partners adopted seasonal roles together with migrant black African workers hired as/when required (Alford et al. 2017). By contrast to factory and other workplace environments these conditions worked to restrict labour organising, with worker resistance more commonly reflecting 'individual appeals, consensual negotiations and methods which sought to avoid open conflict (Alford et al. 2017: 728; Ewert and Du Toit, 2005: 329). As part of a coercive-paternalist regime, industry specific control techniques included the so-called 'dop' system: A form of payment/control based on the gifting of alcohol to workers, stimulating high rates of alcohol dependence among workers (Du Toit et al. 2008). The historical legacy of these practices cannot be ignored when interpreting modern-day work regimes in South African farming/wine production. 
At the same time, since the fall of apartheid in 1991 South Africa has developed a progressive constitution in the interests of protecting workers and departing from colonial legacies of exploitation. Successive African National Congress (ANC) governments have sought to reframe labour relations in South Africa with a view to developing a more equitable approach to regional development. Adding to the ratification of several ILO Conventions ${ }^{6}$, the South African government implemented the Labour Relations Act (LRA) in 1995 as a means of expanding labour's organising rights under a single system of industrial relations (Southall, 2013). Other Acts of note included the Extension of Security and Tenure Act (ESTA, introduced in 1997) which underwrites security of tenure to farmworkers living on farms, while the first minimum wage was set by Sectoral Determination in 2003. These and other legislative Acts have placed pressure on firms to develop more progressive labour relations and humane control regimes in which workers are better placed to negotiate with their employers.

\section{The changing regulation of South African wine}

Legislation has also impacted the wine/farming sector in specific ways. Further to the growth of worker rights, changing state-capital relations have added economic pressure on producers through the phasing out of tariff protections and subsidies, forcing wine capital to engage with a global market place through production networks at the same scalar resolution (see Visser and Ferrer, 2015). The transition towards an enforced strategic alignment with GPNs has proved problematic for many producers, marked by pressure to accept low prices for orders from powerful European retailers (wine producers are thus 'price takers'; see Hughes et al., 2013). In turn, and as part of a reaction to improved labour rights and ESTA, producers have increasingly turned to labour brokers as a means of delivering a temporary workforce (including high numbers of migrant workers) as and when required (Alford et al., 2017). This trend towards casualization poses a significant threat to already low union membership rates which have been estimated at between 5 to 10\% for farm workers (Visser and Ferrer, 2015: 200). Coinciding with this trend, human rights reports have noted the persistence of exploitative labour regimes in which workers are underpaid and in many cases suffering similar indignities to those endured under apartheid (Human Rights Watch, 2011). The continuation of such conditions is testament to the persistence of 
longstanding power relations/hierarchies which workers struggle to contest, irrespective of new networks of economic relations and governance techniques ${ }^{7}$.

Within this context the state labour inspectorate (Inspection and Enforcement Services - IES) has struggled to uphold worker rights in South Africa due to resourcing challenges, linked in particular to low staff numbers and turnover (Hastings, 2016; Hastings and Heyes, 2016; ILO, no date). Labour inspectors may issue compliance orders against employers who break statutory obligations which can be made into/enforced as orders of the Labour Court where financial penalties may result from noncompliance to obligations $^{8}$. Labour inspectors can also shut down operations which are deemed to threaten he health and safety of workers. Despite these powers, in a recent report Kretzmann (2017) noted the Department of Labour had just one inspector for every 120,000 economically active citizens, a figure which compares unfavourably to the ILO's recommended rate of one for every 20,000 (Kretzmann, 2017). In addition, only $60 \%$ of employers who fail to comply with a notice. In the context of the South African wine industry, the inspectorate faces the added challenge of monitoring a vast Western Cape landscape (the wider Western Cape is roughly the same size of Greece; see Figure 1). In responding to this spatial/resource-based challenge a number of polycentric private regulatory organisations have emerged to help monitor and improve labour standards in South African wine and agriculture, including WIETA, the Sustainability Initiative of South Africa (SIZA) ${ }^{9}$ and Fairtrade.

\section{(Insert) Table 1: The WIETA Code (abbreviated)}

Building on pilot work by the ETI, WIETA was founded in November 2002 as a non-profit/voluntary multi-stakeholder initiative (MSI) intended to improve labour and environmental standards in South Africa's wine industry (see Table 1; Bek et al., 2007; Blowfield, 2002; McEwan and Bek, 2009). Based in Stellenbosch (see Figure 1), WIETA plays a potentially significant role in the development of production networks, local labour control regimes and corresponding experiences of workers at the local scale in farms based throughout the Western Cape (Bek et al., 2007), with a remit to audit farms and cellars involved in wine production supply chains in South Africa (WIETA uses third party auditors). In turn, wine farms/producers are encouraged to join WIETA and adhere to the WIETA code 
(itself linked to ILO codes and the Ethical Trade Initiative mandate; see Table 1) to improve access to global markets and European retailers.

\section{(Insert) Table 2: The WIETA board in 2016}

Stakeholder organisations seek membership of the WIETA board for particular reasons, reflecting subjective efforts to influence conditions in the wine industry in South Africa (e.g. in favour of labour or capital interests). From the above list ${ }^{10}$ (see Table 2), industry stakeholders identified WIETA as a means to educate producers on the merits of progressive CSR/Human Resource Management (HRM) initiatives, and for projecting a positive image of labour standards conducive to sustaining supply chain relations (primarily with European retailers). By contrast, a persistent motive from unions and NGOs has been WIETA's role in facilitating union access on accredited farms (author's interviews), potentially improving the structural power for workers at the local level. However, not all South African unions have perceived these benefits: In particular, the influential left-wing Commercial Stevedoring and Allied Workers Union (CSAAWU) has historically refused to collaborate with WIETA due to concerns over the role of industry in WIETA's constitution and the risk of regulatory co-option by wine capital.

The following section discusses WIETA's approach to governance, perceived difficulties which have emerged from this, and labour's networked responses.

\section{Contesting WIETA: A Compliance Based Approach to Regulation}

At the beginning of fieldwork (February, 2016), WIETA's approach to auditing and accreditation (a product of Annual General Meetings (AGMs) and accreditation committees) may be surmised as a compliance based approach to regulation in which producers receive notice/opportunities to address areas of non-compliance rather than direct refusals of accreditation (i.e. with respect to the WIETA code; see Baldwin et al. 2012). In line with theoretical understandings of such approaches (ibid.), this tactic was summarised positively by one third party auditor as preferable to traditional 'command and 
control' or 'big stick' approaches to regulation such as threats of prosecution for producers failing to comply with labour legislations (i.e. by contrast to approaches geared to educating alone):

'... with the Department of Labour it's very much black and white. "It's a non-compliance if you haven't done this" - (so) almost the big stick approach. With Fairtrade, WIETA and SIZA it's more of a journey. So you prioritise and say "these are the critical findings, you need to fix these first" - and it's not something you want to see in three years' time again.' (Interview, trainee auditor, 2017)

In turn, industry stakeholders voiced approval for this advisory approach to regulation (i.e. involving dialogue and 'second chances'; author's interviews), while unions and NGOs saw this approach as weak/ineffectual, reflecting an alleged co-option of the WIETA board by industry stakeholders (author's interviews). In particular, several interviewees questioned whether or not producers were actually penalised for failing audits, leading to accusations that WIETA 'lacked teeth' and (in line with the views of CSAAWU) had been 'hijacked' by big business as a means of covering up illegitimate working practices. Despite the seeming parity on the WIETA board (i.e. a five v. five split of labour and industry stakeholders), NGO and union interviewees pointed to the rise of a 'yellow' organisation on the WIETA board (the National Farm Workers Forum) which was seen to have extended a strong industry bias in the development and handling of audits (authors' interviews). For some interviewees this move was seen to reflect a longstanding WIETA bias in favour of industry. Accordingly:

'I was part of the discussions when they went to Joburg (sic) to form WIETA. Unions were prominent but somehow they lost control...they allowed the captains of industry to hijack the process and they diluted everything that we were discussing here in Cape Town that I was part of. They were diluting everything. And a number of things that we said, like for example the visits on the farms, the evaluations, whether there's compliance or non-compliance, those things became almost choreographed, you know?' (Interview, South African union, 2017). 
In the eyes of several stakeholders, the effectiveness of WIETA audits were seen as contingent on producers themselves and their willingness to engage in genuine reforms to address areas of noncompliance. Several interviewees expressed frustration at a lack of worker/union power to mediate in the auditing process and difficulties encouraging repeat audits or inspections in the event of ongoing worker disputes (author's interviews). Spatial-temporal features proved key to this frustration, based on infrequent farm audits (commonly every 3 years) by third parties and notice periods which allowed for the 'choreographing' of false displays of compliance (e.g. the false installation of temporary toilets on the day of an inspection; authors' interviews $)^{11}$. As noted in previous research on WIETA (in particular frustrations on the part of labour stakeholders) the MSI was viewed by many as ineffective in addressing labour exploitation on farms, or else complicit in sustaining punitive labour regimes in the interests of producers.

The following section examines worker responses to this frustration and in doing so builds on the past inquiries into WIETA/MSI regulation (Bek et al. 2007; McEwan and Bek, 2009). Specifically, it examines the networked capabilities of worker groups based in South Africa and Scandinavia, and the relational effects of recent transnational collaborations on the regulation of wine capital in the Western Cape (Allen, 2003).

Labour's associational agency: transnational flows of pressure

Since the last period of research on WIETA (at least from a geography perspective; see Bek et al. 2007; McEwan and Bek, 2009), agricultural unions/NGOs in South Africa have sought to utilise connections with likeminded actors in strategically important European markets. This building of associational agency is illustrated by the Ethical Wine Trade Campaign (EWTC): A collaboration of worker organisations and solidarity movements across South Africa, Sweden, Chile and Argentina (important wine regions globally) as a means of sharing information/resources and challenging structural constraints. The EWTC proved key to identifying the importance of Nordic alcohol monopoly retailers in Sweden (Systembolaget) and Norway (Vinmonopolet) within South African wine GPNs, and the role 
of buyer pressure in driving improvements to labour standards on wine farms. Faced with consumer pressure in their respective countries, Systembolaget and Vinmonopolet regulate their supply chains through tender procedures and the use of the Business Social Compliance Initiative (BSCI, now known as Amfori BSCI) which aims to improve social conditions in supply chains ${ }^{12}$. Based on this knowledge, past tactics of the EWTC included a whistleblowing letter to Systembolaget in 2013 citing labour rights violations from key suppliers in the Langeberg Municipality and other areas of the Western Cape ${ }^{13}$. Thus:

'I complained to WIETA (and) I sent the grievances to the employer. This was a foreign owned wine farm with local managers that were very conservative and doing the least they can, but it was such a good farm on the eye...There were aspects of audit fraud on here, health and safety non-compliance, everything. Meanwhile WIETA had its processes to follow up. (Instead of waiting) I sent a letter straight to Systembolaget to say 'you are buying from these people, but there are non-compliances - speak to this'... So you see the network and how we use it to apply pressure.' (Interview, South African CSO/WIETA board member, 2016)

Unconvinced by actions resulting from the above, in 2016 South African agricultural unions and NGOs (including CSAAWU and Sikhule Sonke) collaborated with Danish filmmaker Tom Heinemann in the production of Bitter Grapes: A critical documentary into work conditions in South African wine. Facilitated by union and NGO inputs in both South Africa and Scandinavia, Bitter Grapes emerged from the powers of association between different South African and Scandinavian actors joined through common concerns over work conditions on South African wine farms ${ }^{14}$. In aiding its production, labour stakeholders sought to invoke both moral and political energies to influence wider European audiences, and, in turn, key influencers of work conditions such as the Nordic monopolies themselves and WIETA (Allen, 2003; Chun 2009). Subsequently, Heinemann's documentary painted a damning picture of exploitation on wine farms in which WIETA had essentially struggled to enforce worker rights, including coverage of alcoholism in farming communities, underpayment of wages, unsafe working/living conditions (e.g. health and safety concerns over the use of pesticides) and illegal efforts 
by producers to obstruct worker organising efforts in multiple farms (footage was especially scathing of the leading producer Robertson wines). CSAAWU featured prominently in these accounts, depicting slave-like conditions on farms congruent with previous eras of racial exploitation under Apartheid. In doing so Bitter Grapes evoked moralistic outrage and support for urgent change wine farm regulation via a wave of negative publicity in South Africa and Scandinavia where the documentary first aired (Chun, 2009).

Despite industry efforts to discredit findings (Vinpro focussed on bias in the documentary, while WIETA noted the selectivity of cases), pressures from Scandinavian consumers/retailers followed suit, marked by the delisting of Robertson wines by Danish supermarket chain Dagrofa, together with statements of intent from the main Nordic monopoly retailers. Of these, Vinmonopolet of Norway went as far as to thank Tom Heinemann for his work, backed with a commitment to independently investigate wine farms and alter purchasing practices depending on findings (see below). Building on pre-existing disputes between CSAAWU and a number of wine farms/producers, unions and NGOs were thus able to mobilise their (local) horizontal knowledge of exploitation on wine farms and project this onto the global stage, triggering vertical pressures along the wine supply chain to reform the regulation of the industry (the power of the Nordic wine monopolies was especially important in this respect; key parallels are thus evident with the work of Anderson, 2013). Relational effects of this pressure may be read in a series of adjustments to key governance institutions including WIETA and the South African Department of Labour, marking a change in the political-regulatory pressures facing wine producers in the Western Cape. Changes in the regulatory approaches of the South African labour inspectorate, European retailers and WIETA itself are now considered in turn.

Shifting regulations: new approaches to public and private governance

Following Bitter Grapes the South African labour inspectorate (the IES) undertook a series of new investigations into wine farms in the Western Cape, focussing firstly on cases identified in Bitter Grapes. Subsequently, investigations of five farms in the Drakenstein and Robertson (November 2016; 
see Figure 1) verified unsafe work conditions, substantiating longstanding complaints by labour unions which had previously gone unheard. Dissatisfied with existing efforts to improve labour standards (notably WIETA's role and the role of industry-led audits), these findings have since justified a heightened focus on wine farms more generally within the region:

'Initially they (labour inspectors) went out to all the farms that were in the film. They found more errors, and they handed out a lot of fines and threats to close down (operations) and the authorisation to export wine...They were quite rigorous. It was about time.' (Interview with Tom Heinemann, 2018).

Building on these inspections the IES has also sought to understand and complement the role of WIETA to better effect, undertaking a comparative benchmarking of the WIETA code/audit process. This exercise came with a view to debunking the notion that WIETA accreditation equates to labour law compliance (a point erroneously taken up by certain producers; author's interviews). Other, more widespread adjustments have included a commitment to better cooperate with local agricultural unions as a means of identifying wine farms suspected of breaking labour laws, with one labour inspector describing local farm unions as the new 'eyes and ears' of the inspectorate (author's interviews). This increasing role for unions in the monitoring of work conditions has been matched by changing interfirm relations driven by both Systembolaget and Vinmonopolet involving a greater role for both local and international unions in monitoring South African wine. In the case of Systembolaget a memorandum of understanding was signed with the International Food Workers' Federation (IUF, a federation of different agricultural unions) in 2017, marking an agreement for union support in monitoring/reporting on labour conditions in farms. It is hoped that new trends to incorporating worker unions/NGOs in this way may lead to more genuine cooperation paradigms in which workers maintain voice/agency while working with producers to improve work conditions (Lund-Thompson and Lindgreen, 2014; author's interviews). Accordingly:

'After Bitter Grapes we realised that WIETA needed to improve the workers' voice and play a role in this. I think auditing is one thing, and something that WIETA always has to do...(but we also) signed 
a Memorandum of Understanding with IUF in August 2017. It's short, but it says that we would like their help and knowledge of labour unions to gather any breaches of our code of conduct or national labour laws so we can be made aware of these breaches and take action.' (Interview, Systembolgaet, 2018).

Subsequent to these findings the Norwegian monopoly retailer Vinmonopolet developed a new 8-point requirement for producers in addition to/in line with their existing Amfori BSCI requirements (see Table 3). Coupled with this requirement, under the new 8-point requirement producers found guilty of noncompliance on these points were subsequently required to address shortcomings in as little as 3 months or else face a withdrawal of orders.

'When Bitter Grapes first came out we didn't have 6 months, we needed to do something immediately ...what we did was we broke it down to eight specific points that seemed to be the problem, and we created our own requirements... in a way we were hoping that the producers would use this opportunity that was now given to them, use the 3 months to work hard and remedy what the issue is, and when we came with our third party auditors we would have a verification that everything now was in order - but that unfortunately was not the case.' (Interview, Vinmonopolet, 2018)

In the same year Vinmonopolet commissioned a series of independent audits (22 in total) confirming documentary findings (e.g. denials of union access and worker payment violations) and instances of worker harassment. Out of the 22 audited facilities, $18 \%$ were viewed as 'critical', with $41 \%$ classed as holding 'intermediate' risk levels based on visual observations, worker and management interviews and documentation conducted by the authors on the dates of site visits (author's interviews).

(Insert) Table 3: Vinmonopolet: abbreviated 8 points requirement (points 1 and 2 in relation to the BSCI code of conduct) 
Based on pressure from the Nordic monopolies WIETA subsequently developed new internal reforms, including agreement to undertake a full benchmark comparison of its own audit processes against the latest BSCI Version 2 (now Amfori) in 2017 on the back of new board elections wherein the 'yellow' NFWF was removed from the WIETA board (author's interviews). Significant changes followed, including an agreement to recalibrate WIETA's approach to regulation by shifting from techniques based solely on intermittent efforts at nudging producers to improve conditions through infrequent 3year audit intervals (i.e. at a distance), to more proximate (i.e. frequent) forms of pressure based on 2year audit cycles and full repeat audits for producers with poor records of compliance. Again in August 2017, WIETA created a new compliance scale/risk matrix including a more granular rating scale from A-E in reflection of high-low risk compliance rates on farms. This adjustment marked a step-change in auditing procedures in which farms would not receive a WIETA certificate if they failed to receive a category ' $\mathrm{C}$ ' or higher. Supplementing this change WIETA committed to broadcasting audit reports with higher levels of online transparency. Subsequently:

'Now the buyers from Scandinavian monopolies can actually see 'well this guy is an A rating, he's very very low risk, in fact hardly any risk at all...(whereas) this guy is an E because he's an extremely high risk...(and) if you get a $\mathrm{D}$ or an $\mathrm{E}$ you have to submit the corrective actions onto our systems, but then you need to be re-audited ${ }^{15}$ (Interview, WIETA, 2018)

Advancements in online reporting systems are intended to improve adherence to the WIETA code through more effective forms of inducement (i.e. positive publicity and subsequent market access for attaining the highest standards of compliance). Equally, the same approach may be read as a succumbing to longstanding labour stakeholder calls for WIETA to punish non-complying firms (e.g. the use of a 'big stick') by delivering real reputational damage to firms which fail to comply or score lowly on WIETA audits. This represents a deviation from WIETA's previous refusal to "fail' or shame producers' in the interests of educational merits and strictly compliance based approaches to regulation (Bek et al. 2007: 308; McEwan and Bek, 2009: 726). Coupled with the enhanced role of unions in monitoring conditions, this leveraging of pressure has led to new/cross-cutting modalities of power 
(Allen, 2004) ranging from persuasive approaches (e.g. positive 'A' score/publicity for compliant producers) to the threat of sanction in the event of non-compliance (in theory, negative scores may ultimately lead to the de-coupling from GPN arrangements).

It remains to be seen whether the above reforms will realise improvements to work conditions in practice as well as theory (a longstanding criticism of WIETA and other MSIs). Categorising WIETA's approach to regulation is also challenging, due, in part, to the nature of ongoing reforms and the contestation discussed. As noted by Lund-Thomsen and Lindgreen (2014), compliance based models of regulation typically involve corporate codes of conduct/ethical guidelines linked to third party audits, and in this sense (like the ETI more broadly) WIETA still aligns to this approach. It is also still geared to developmental ambitions involving long-term improvements in labour conditions in value chains based on the education of producers (e.g. encouraging enhanced HRM/CSR initiatives; author's interviews; Lund-Thomsen and Lindgreen, 2014: 13). At the same time recent adjustments suggest a new 'corporate cooperative paradigm' is emerging within WIETA, driven by labour's proactive campaigning (ibid.). This model similarly promotes social upgrading through longer-term trust-based relations between buyers and first-tier suppliers though with greater emphasis on horizontal relations (notably the role of local NGOs and trade unions) in which value chains are embedded, stressing the importance of local socio-economic and socio-cultural contexts in regulating employment. While trust between international buyers and suppliers has clearly eroded following Bitter Grapes, the intention is for third parties (in particular unions) to play their mediating role in the interests of longer-term harmonious trade relations based on sustained improvements to work conditions in supply chains (authors' interviews). Further research is required to better understand which category/regulatory paradigm WIETA now falls under following these labour-driven internal reforms.

\section{Conclusion}

In response to recent calls for an extended application of the GPN framework (Cumbers, 2015), this paper has examined the associational powers of workers and labour-driven relational effects on the regulation of wine farms in South Africa. Focussing on transnational campaigning between 
Scandinavian unions/NGOs and South African counterparts (notably CSAAWU), networks of alliance across national borders have helped spur regulatory changes within and through international retailers, WIETA and the South African state labour inspectorate. Through the EWTC and Bitter Grapes in particular, South African unions/NGOs have generated moral/political appeals from European consumers through symbolic leverage (Chun, 2009), leading to more stringent inter-firm monitoring by leading Nordic buyers and more proximate labour inspection and auditing processes from extra-firm regulators (e.g. WIETA and the state labour inspectorate). Acknowledging the process-based nature of power (i.e. power is not held or contained, but rather mediated; Allen, 2003) a stronger role for unions as the 'eyes and ears' on the ground has also emerged as a result of networked pressure.

Related studies have stressed the role of labour in encouraging the use of private standards in supply chains (e.g. the uptake of social certifications in banana supply chains, see Riisgaard and Hammer, 2011). The paper contributes to this discussion by extending analysis of labour's role to influencing the manner in which private standards are monitored/enforced. Without this appreciation of wider relational geographies (and labour's role within these), research has more commonly focussed on internal politics and resulting corporate bias in MSIs, undermining labour's potential to shape private regulation and in turn alter the monitoring of local labour control regimes (Dolan and Opodo, 2005; Fransen, 2012; Fransen and Kolk, 2007). Using GPN frameworks to cast light on labour's own networks, labour's associational powers are shown as key in both contesting WIETA internally and developing platforms for connecting worker interests/struggles more globally. In shifting the politics of extra-firm regulatory institutions, labour in turn drives new configurations of social relations within wine GPNs, opening up the potential for more progressive work conditions in which workers play an active role maintaining standards, rights and entitlements.

At the same time acknowledgement is made of the continued challenges workers face in remote industries such as wine farming, and the prospects for sustained change as a result of more proximate regulation. In particular, the power of Western retailers continues to direct price pressure on producers in the Global South, who in turn foot the bill for more onerous labour/environmental standards 
adherence. The result encourages further squeezing of labour's pay and conditions currently observed in the heightened use of temporary workers which further undermines labour's organising efforts (for longstanding discussions on retailer power in this respect, see Hughes, 2001; Hughes et al. 2013; Riisgaard and Hammer, 2011). Equally, it remains to be seen whether labour unions will capitalise on new opportunities presented in the above reforms (a long-standing question with respect to WIETA; see Visser and Godfrey, 2017). The prospects of sustained union agency (structural or associational) have undoubtedly been bolstered as a result of successful transnational campaigning, with associational power and the use symbolic leverage placing pressure on producers to better support worker organising rights on farms in particular (Bank Muñoz, 2018; Chun 2009; Silver 2003) ${ }^{16}$. Nevertheless, future research is needed to appraise the short-long term effects of recent regulatory changes on work conditions in practice within South Africa's globally integrated wine industry.

\section{Notes}

\footnotetext{
${ }^{1}$ Findings are based on primary research conducted between 2015 and 2018. During this period a total of 59 interviews took place with stakeholders with expertise in labour administration/inspection in different regions of the world (UK, Ireland, USA, South Africa). An interest in WIETA emerged in the course of developing a training toolkit for the ILO intended for labour inspectors monitoring work in the informal economy (Heyes and Hastings, 2015). Four trips to South Africa were undertaken, facilitating 23 interviews with wine/fruit industry stakeholders (including interviews with WIETA members, trade unions, NGOs and producers and a focus group with state labour inspectors). In addition, four telephone interviews took place with a correspondent from WIETA, the journalist Tom Heinemann and officials from the Nordic monopoly retailers (Systembolaget and Vinmonopolet) in 2018. In 2019, nine further interviews took place with industry, union and NGO stakeholders in Norway and Sweden which helped fact-check findings presented in this paper (this included interviews with representatives of the alcohol monopoly retailers for Systembolaget in Sweden and Vinmonopolet in Norway, trade unions and NGOs campaigning for labour standards improvements in South Africa).

${ }^{2}$ Read in this light, a restricted GPN perspective may interpret MSIs as 'region-specific assets' which complement the strategic needs of focal firms in GPNs who desire wider market access (Coe et al. 2004; Cumbers, 2015).
} 
${ }^{3}$ For South Africa as a whole the wine industry generated around R36,145 million in GDP in 2013, employing close to 290,000 workers directly and indirectly (Sawis, 2015: 25). This figure includes farm labourers and workers involved in packaging, retailing and wine tourism.

${ }^{4}$ The full total import trade value was $\$ 2,062,798,775$ in 2017 based on commodity code HS 2204 (wine of fresh grapes, including fortified wines); within these figures Sweden and Norway spent \$727 million and \$416 million respectively. See https://comtrade.un.org/data/

${ }^{5}$ Though not without controversy the term 'Coloured' is a formal, composite racial category in South Africa which refers to people of multiple heritage, specifically 'the descendants of relationships between white and black people, the descendants of 'Malay' slaves brought from South-East Asia (categorised separately in 1951 but not thereafter), and (after 1970) descendants of the indigenous Khoi and San who inhabited the Western Cape prior to the arrival of either white or black people' (Seekings, 2008:3).

${ }^{6}$ E.g. Convention 87 (Freedom of Association and Protection of the Right to Organise) and Convention 98 (Right to Organise and Collective Bargaining). South Africa also subscribed to the Convention 81 on Labour Inspection in June 2013

${ }^{7}$ Direct resistance was marked by violent protests over the course of 2012-2013 in the Du Doorns and Worcester areas in the Western Cape (see Figure 1). Protests included road blockades and the burning of property by workers frustrated at low pay, high rates of unemployment and the lack of adequate accommodation (see also Alford and Phillips, 2018). Resistance encouraged the uptake of a new minimum wage which has since risen by as much as $52 \%$ to R128.26 for a nine-hour day, although violence further eroded already low levels of trust between producers, trade unions and workers (authors' interviews; BusinessTech, 2016; News24, 2016).

${ }^{8}$ In recent years only around $60 \%$ of those failing to comply with notices were likely to face referral for prosecution (Kretzmann, 2017).

${ }^{9}$ The Sustainability Initiative of South Africa (SIZA) is a membership based non-profit organisation designed to assist fruit growers with ethical labour/environmental practice compliance.

${ }^{10}$ At the start of the South African fieldwork (late 2015) the WIETA board was composed of ten members in theory reflecting a 50/50 balance between industry and labour stakeholders (see Table 2).

${ }^{11}$ Unions observed common failures surrounding health and safety concerns (e.g. training on machinery, use of pesticides, access to clean toilets), underpayment of wages/failure to supply legal documentation to workers (e.g. relating to production payslips, records of the numbers of workers formally employed) and unfit worker housing (authors' interviews). 
${ }^{12}$ Amfori BSCI is based on a different code of conduct to WIETA and incorporates alternative tools/activities to audit, train and influence key actors geared to improving labour conditions in supply chains.

${ }^{13}$ Stakeholders responsible for the letter included CSAAWU (South African farm workers' union); Sikhula Sonke (South African farm workers' union); Bawusa (South African farm workers' union); UST (Argentinian farm workers' organization); ANAMURI (Chilean farm workers' organization); SAC (Systembolaget shop workers' union); Livs, procordia club (Swedish food processing union); Afrikagruppena (Swedish solidarity organization); Latinamerikagrupperna (Swedish solidarity organization).

${ }^{14}$ Danish solidarity organisation Afrika Kontakt and Swedish NGO Afrikagrupperna (an original member of the EWTC) acted as key gatekeepers in this respect, helping to facilitate Tom Heinemann's links with South African trade unions (notably CSAAWU).

${ }^{15}$ Here 'risk' may be read as a risk of violating the WIETA code, resulting low audit scores which threaten a decoupling from supply chains.

${ }^{16}$ These links between associational and structural power (i.e. the latter most obvious in the ability to strike at key points of production) are also evidenced in a direct material benefit from associational links to Scandinavia in the case of CSAAWU. In April 2017 CSAAWU received the Arthur Svensson International Prize for Trade Union Rights from the Norwegian People's Aid, complete with a gift of 500,000 Norwegian krone from the Norwegian labour union Industri Energi. This funding has helped to allay a recent history of financial troubles for CSAAWU, working to support continued union activities in the region. 


\section{Bibliography}

\section{AUTHOR A}

Allen, J. (2003) Lost Geographies of Power, Blackwell: Oxford.

Allen, J. (2004) The Whereabouts of Power: Politics, Government and Space. Geografiska Annaler: Series B, Human Geography, 86: 19-3.

Alford, M., Barrientos, S., Visser, M. (2017) Multi-scalar Labour Agency in Global Production Networks: Contestation and Crisis in the South African Fruit Sector. Development and Change, 48: $721-74$.

Alford, M and Phillips, N. (2018) The political economy of state governance in global production networks: change, crisis and contestation in the South Africa fruit sector. Review of International Political Economy, 25: 98-121.

Anderson, J. (2013) Intersecting arcs of mobilisation: The transnational trajectories of Egyptian dockers' unions, European Urban and Regional Studies. 20(1): 128-133.

Aurand, J.-M. (2018) 'Estado del mercado global en la vitivinicultura'. Available at: http://www.oiv.int/public/medias/6370/state-of-the-world-vitiviniculture-oiv-2018-ppt.pdf.

Bäckstrand, K. (2006) Multi-Stakeholder Partnerships for Sustainable Development: Rethinking Legitimacy, Accountability and Effectiveness, European Environment, 16: 290-306

Baldwin, R., Cave, M., Lodge, M., (2012) Understanding Regulation: Theory, Strategy, and Practice. Oxford: Oxford University Press. 
Bank Muñoz, C. (2017) Building Power From Below: Chilean Workers Take on Walmart. London: Cornell University Press

Barrientos, S., Gereffi, G., Rossi, A. (2011) Economic and social upgrading in global production networks: A new paradigm for a changing world, International Labour Review, 150: 319-340.

Barrientos, S. (2013) Corporate Purchasing Practices in Global Production Networks: A Socially Contested Terrain, Geoforum 44: 44-51.

Bartley T (2018) Rules without Rights: Land, Labor, and Private Authority in the Global Economy. Oxford: Oxford University Press.

Bek, D., McEwan, C., Bek, K. (2007) Ethical trading and socioeconomic transformation: critical reflections on the South African wine industry, Environment and Planning A, 39: 301-319.

Bieler, A. (2018) Agency and the Power Resources Approach: Asserting the Importance of the Structuring Conditions of the Capitalist Social Relations of Production, Global Labour Journal, 9(2): $243-248$.

Birelma, A. (2018) When Local Class Unionism Meets International Solidarity: A Case of Union Revitalisation in Turkey, Global Labour Journal, 9(2): 215-230.

Blowfield, M. (2002) ETI: a multi-stakeholder approach. In R. Jenkins, R. Pearson, G. Seyfang (eds) Corporate Responsibility and Labour Rights: Codes of Conduct in the Global Economy, pp. 184-195. London: Earthscan.

Bourdieu, P. (2000). Pascalian Meditations. Stanford, CA: Stanford University Press. 
Brookes, M., Riverside, C., States, U. (2018) 'Global Issues Power Resources in Theory and Practice : Where to Go from Here', 9(2), Global Labour Journal, 9(2 ): 254-257.

BusinessTech (2016) SA farm workers get minimum wage increase, Available at: https://businesstech.co.za/news/wealth/111183/sa-farm-workers-get-minimum-wageincrease/ (Accessed: 27/01/2019).

Büthe, T., Mattli, W. (2011) The New Global Rulers: The Privatization of Regulation in the World Economy. Princeton, NJ: Princeton University Press.

Carswell, G. and De Neve, G. (2013) Labouring for global markets: Conceptualising labour agency in global production networks, Geoforum. 44: 62-70.

Christopherson, S., Lillie, N. (2005) Neither global nor standard: corporate strategies in the new era of labor standards. Environment and Planning A, 37: 1919-1938.

Chun, J. J. (2009) Organizing at the margins: The symbolic politics of labor in South Korea and the United States. London: Cornell University Press.

Coe, N. M. (2012) Geographies of production III, Progress in Human Geography, 37(2): 271-284.

Coe, N.M., Dicken, P., Hess, M. (2008) Global production networks: realizing the potential. Journal of Economic Geography, 8: 271-295.

Coe, N. M., Hess, M. (2013) ‘Global production networks, labour and development’, Geoforum. 44: 49. 
Coe, N.M., Hess, M., Yeung, H. W. C., Dicken, P., Henderson, J. (2004) 'Globalizing' regional development: a global production networks perspective. Transactions of the Institute of British Geographers, 29(4): 468-484.

Coe, N., Jordhus-Lier D.C. (2011) Constrained agency? Re-evaluating the geographies of labour. Progress in Human Geography, 35(2): 211-233.

Cumbers, A. (2015) Understanding Labour's Agency under Globalization: Embedding GPNs within an Open Political Economy. In P. Taylor., K. Newsome, J. Bair and A. Rainnie A (eds) Putting Labour in its Place: Labour Process Analysis and Global Value Chains, pp. 135-151. London: Palgrave.

Cumbers, A., Featherstone, D., MacKinnon, D., Ince, A., Strauss, K. (2016) intervening in globalization: the spatial possibilities and institutional barriers to labour's collective agency. Journal of Economic Geography, 16: 93-108.

Del Casino, V. J, Grimes, A. J., Hanna, S.P., Jones III, J.P. (2000) Methodological frameworks for the geography of organizations. Geoforum, 31(4): 523-538.

Dicken, P. (1986) Global Shift: Industrial Change in a Turbulent World. London: Paul Chapman.

Dolan, C., Opondo, M. (2005) Seeking Common Ground: Multi-stakeholder Processes in Kenya's Cut Flower Industry. The Journal of Corporate Citizenship, 18: 87-98.

Du Toit, A., Kruger, S., Ponte, S. (2008) Deracializing Exploitation? 'Black Economic Empowerment' in the South African Wine Industry. Journal of Agrarian Change, 8(1): 6-32.

Eurostat (2018) Wine production and trade in the EU. Available at: https://ec.europa.eu/eurostat/web/products-eurostat-news/-/EDN-20181112-1?inheritRedirect=true 
Ewert, J., Du Toit, A. (2005) A deepening divide in the countryside: Restructuring and rural livelihoods in the South African wine industry. Journal of Southern African Studies, 31(2): 315-332.

Featherstone, D. (2008) Resistance, space and political identities: the making of counter-global networks. Oxford: Wiley-Blackwell.

Featherstone, D. (2012) Solidarity: Hidden histories and geographies of internationalism. London: Zed Books.

Fransen, L.W. (2012) Multi-stakeholder governance and voluntary programme interactions: legitimation politics in the institutional design of Corporate Social Responsibility, Socio-Economic Review, 10: 163-192.

Fransen, L.W., Kolk, A. (2007) Global Rule-Setting for Business: A Critical Analysis of MultiStakeholder Standards. Organization, 14: 667-684.

Fuchs, D., Kalfagianni, A., Havinga, T. (2009) Actors in private food governance: the legitimacy of retail standards and multi-stakeholder initiatives with civil society participation. Agriculture and Human Values, 28: 353-367.

Hastings T (2016) Technical Report No.2 ILO Workshop on Labour Administration Reforms and Innovations: Efficiency and Outreach. International Labour Organization Geneva. Available online: https://www.ilo.org/wcmsp5/groups/public/---ed dialogue/--ed dialogue msu/documents/publication/wcms 506152.pdf

Hastings, T. and Heyes, J. (2016) Comparative developments in labour administration Comparative developments in labour administration. International Labour Office, Geneva. Available online: 
https://www.ilo.org/wcmsp5/groups/public/---ed_dialogue/---

ed_dialogue_msu/documents/publication/wcms_506148.pdf[Accessed 20 April 2019].

Hastings, T., MacKinnon, D. (2017) Re-embedding agency at the workplace scale: Workers and labour control in Glasgow call centres. Environment and Planning A, 49(1): 104-120.

Henderson, J. Dicken P, Hess M., Coe N. M., and Yeung, H. W. C. (2002) 'Global production networks and the analysis of regional development', Review of International Political Economy, 9(3): 436-464.

Herman, A. (2014) Are we there yet? Exploring empowerment at the microscale in the South African wine industry. Environment and Planning A, 46: 1927-1945.

Herod A., (2001) Labour Geographies: Workers and the Landscapes of Capitalism. New York: Guildford Press.

Horner, R. (2017) State roles in global value chains and global production networks. Geography Compass, 11(2), 1-13.

Hughes, A. (2001) Multi-stakeholder approaches to ethical trade: Towards a reorganisation of UK retailers' global supply chains. Journal of Economic Geography, 1: 421-437.

Hughes, A., McEwan, C., Bek, D. (2013) Retailers, Supply Networks and Changing Articulations of ethicality: Lessons from Flower Valley in South Africa. Journal of Economic Geography, 13: 211-230.

Human Rights Watch, (2011) Ripe with Abuse: Human Rights Conditions in South Africa's Fruit and Wine Industries. Human Rights Watch, August, 2011. Available online: https://www.hrw.org/sites/default/files/reports/safarm0811 brochure low.pdf $[$ Accessed 20 July 2018]. 
ILO (no date) Labour Inspection Country Profile: SOUTH AFRICA, Available online: https://www.ilo.org/labadmin/info/WCMS 150917/lang--en/index.htm [Accessed 20 April 2019].

Jonas, A. (1996) Local labour control regimes: Uneven development and the social regulation of production, Regional Studies, 30(4): 323-338.

Kelly, P.F. (2013) Production networks, place and development: Thinking through Global Production Networks in Cavite, Philippines, Geoforum, 44: 82-92.

Kretzmann, S. (2017) Labour department can't protect workers. GroundUp. Available online: https://www.groundup.org.za/article/labour-department-cant-protect-workers/ [Accessed 20 April 2019].

LeBaron, G., Lister, J. (2015) Benchmarking global supply chains: the power of the 'ethical audit' regime. Review of International Studies, 41, 905-924.

Locke, R. M., Qin, F., Brause, A. (2007) Does monitoring improve labor standards? Lessons from Nike. Industrial and Labor Relations Review, 61(1): 3-31.

Lund-Thomsen, P. (2013) Labour agency in the football manufacturing industry of Sialkot, Pakistan. Geoforum, 44(1): 61-71.

Lund-Thomsen, P., Coe, N.M. (2015) Corporate social responsibility and labour agency: the case of Nike in Pakistan, Journal of Economic Geography, 15: 275-296.

Lund-Thomsen, P., Lindgreen, A. (2014) Corporate Social Responsibility in Global Value Chains: Where Are We Now and Where Are We Going? Journal of Business Ethics 123:11-22. 
McEwan, C., Bek. D. (2009) Placing Ethical Trade in Context: WIETA and the South African wine industry. Third World Quarterly, 30: 723-742.

McGrath, S. (2013) 'Fuelling global production networks with slave labour?: Migrant sugar cane workers in the Brazilian ethanol GPN', Geoforum, 44, pp. 32-43.

Mena S and Palazzo G (2012) Input and Output Legitimacy of Multi-Stakeholder Initiatives. Business Ethics Quarterly, 22(3): 527-556. Nadvi, K. (2008) Global standards, global governance and the organisation of global value chains. Journal of Economic Geography, 8(3): 323-343.

Newsome, K., Taylor, P., Bair, J., Rainnie, A. (2015) Putting Labour in its Place: Labour Process Analysis and Global Value Chains (Critical Perspectives on Work and Employment). London: Palgrave.

Örnberg, J. C. and Ólafsdóttir, H. (2008) How to sell alcohol? Nordic alcohol monopolies in a changing epoch. Nordic Studies on Alcohol and Drugs, 25(2): 129-153.

O’Rourke, D. (2006) Multi-stakeholder regulation: Privatizing or socializing global labor standards? World Development, 34(5): 899-918.

Peck, J. (2013) Making Space for Agency. In: D. Featherstone, J. Painter (eds) Spatial Politics: Essays for Doreen Massey, pp. 99-114. London: Wiley-Blackwell.

Ponte, S., Ewert, J. (2009) Which Way is "Up" in Upgrading? Trajectories of Change in the Value Chain for South African Wine. World Development, 37: 1637-1650.

Rainnie, A., Herod, A. and McGrath-Champ, S. (2011) Review and Positions: Global Production Networks and Labour. Competition \& Change, 15(2): 155-169. 
Rasche, A. (2012) Global Policies and Local Practice: Loose and Tight Couplings in Multi-Stakeholder Initiatives. Business Ethics Quarterly, 22: 679-708.

Riisgaard, L.,Hammer, N. (2011) Prospects for Labour in Global Value Chains: Labour Standards in the Cut Flower and Banana Industries. British Journal of Industrial Relations, 49(1):168-190.

Ruwanpura, K.N. (2016) Garments without guilt? Uneven labour geographies and ethical trading - Sri Lankan labour perspectives. Journal of Economic Geography, 16: 423-446.

South African Wine Industry Information and Systems (SAWIS) (2015) 'Macro-economic impact of the wine industry on the South African economy (also with reference to the impacts on the Western Cape)', Conningarth Economists, 3(January), pp. 1-62. Available online: http://www.sawis.co.za/info/download/Macro-economic_impact_study_-

Final Report Version 4 30Jan2015.pdf. [Accessed 20 April 2019].

South African Wine Industry Information and Systems (SAWIS) (2019). Available online: http://www.sawis.co.za/info/stats exports_2018.php [Accessed 20 April 2019].

Schmalz, S., Ludwig, C., Webster, E. (2018) The Power Resources Approach: Developments and Challenges', Global Labour Journal, 9(2): 113-134.

Schmalz, S., Ludwig, C., Webster, E. (2019) Power Resources and Global Capitalism, Global Labour Journal, 10(1): 84-90.

Seekings J. (2008) The continuing salience of race: Discrimination and diversity in South Africa. Journal of Contemporary African Studies, 26:1, 1-25. 
Selwyn, B. (2013) Social Upgrading and Labour in Global Production Networks: A Critique and an Alternative Conception. Competition and Change, 17: 75-90.

Silver, B.J. (2003) Forces of Labor: Workers' Movements and Globalization since 1870. Cambridge: Cambridge University Press.

Southall, R. (2013) South Africa. In: Frege, C., Kelly, J. (ed.) Comparative Employment Relations in the Global Economy. pp. 348-365. Oxford: Routledge.

Taylor, P., Newsome, K., Bair, J., Rainnie, A. (2015) 'Putting Labour in its Place': Labour Process Analysis and Global Value Chains. In: Newsome, K., Taylor, P., Bair, J., Rainnie, A. (eds) Putting Labour in its Place: Labour Process Analysis and Global Value Chains (Critical Perspectives on Work and Employment), pp. 1-28. London: Palgrave.

Visser, M., Ferrer, S. (2015) Farm Workers' Living and Working Conditions in South Africa: key trends, emergent issues, and underlying and structural problems. Report based on a research project commissioned by the Pretoria Office of The International Labour Organisation.

Visser, M. Godfrey, S. (2017) Working Paper 49: Are trade unions and NGOs leveraging social codes to improve working conditions? A study of two locally developed codes in the South African fruit and wine farming sectors. Institute for Poverty, Land and Agrarian Studies (PLAAS)

Vogel, D. (2010) The Private Regulation of Global Corporate Conduct: Achievements and Limitations. Business \& Society, 49: 68-87.

Yeung, H. W. C. and Coe, N. (2015) Towards a Dynamic Theory of Global Production Networks. Economic Geography, 91(1): 29-58. 
Wad, P. (2013) Getting international labour rights right at a foreign controlled company in Malaysia: A Global Labour Network perspective, Geoforum. 44: 52-61.

Wright, E.O. (2000) Working-class Power, Capitalist-class Interests, and Class Compromise. American Journal of Sociology, 105(4): 957-1002. 
Figure 1: Map of South Africa's Western Cape

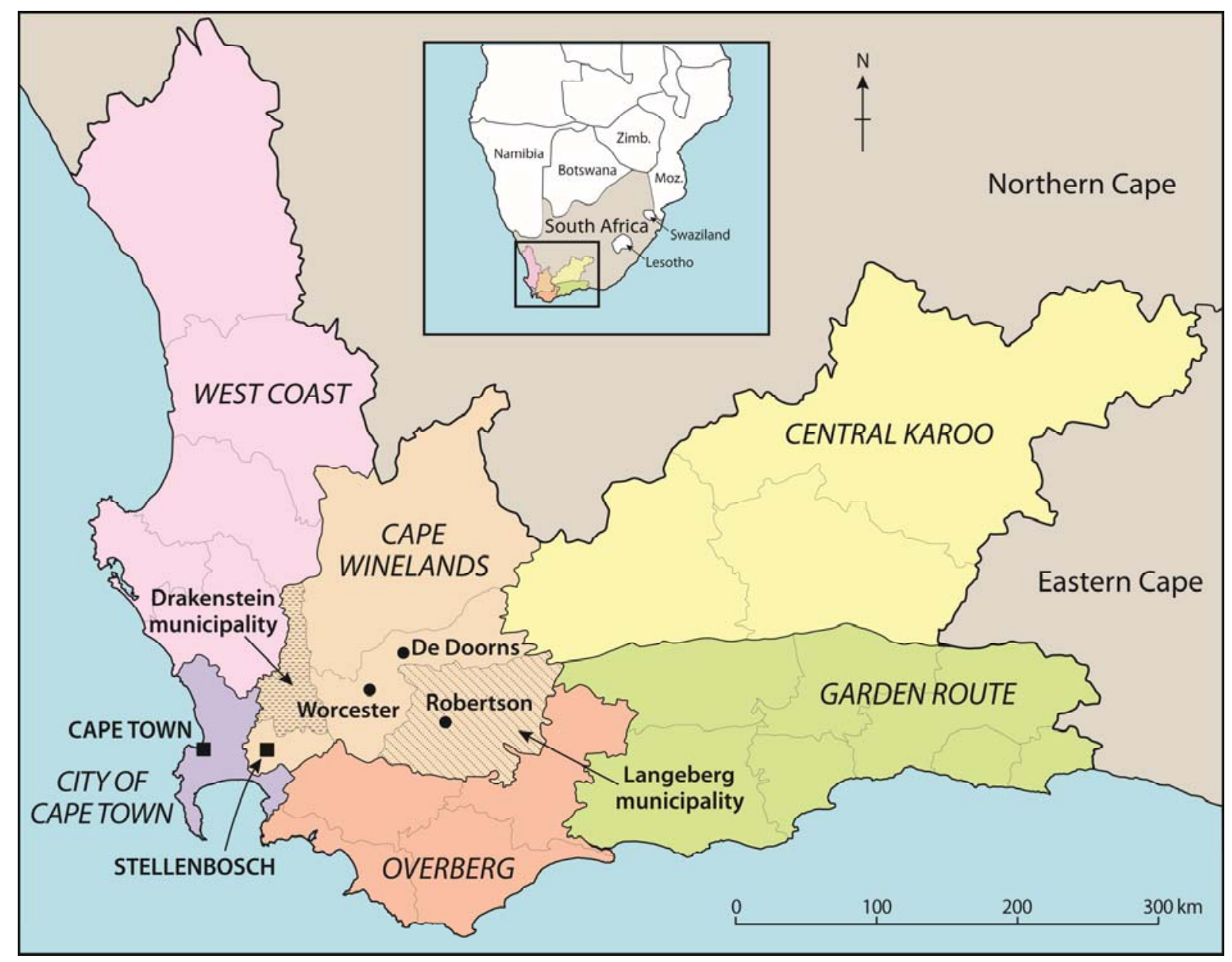




\section{Table 1: The WIETA code of conduct: principles}

- Child labour shall not be utilised.

- Employment shall be freely chosen.

- The right to a healthy and safe working environment.

- The right to freedom of association.

- The right to a living wage.

- Working hours shall not be excessive.

- Harsh or inhumane treatment is prohibited.

- Unfair discrimination is prohibited.

- Regular employment shall be provided.

- Worker's housing and tenure security rights will be respected. 
Table 2: WIETA Board (February, 2016)

\begin{tabular}{|l|l|}
\hline Member organisation & Member type \\
\hline The Centre for Rural Legal Studies & NGO \\
\hline National Farm Workers Forum & NGO \\
\hline Sikhula Sonke & Trade union \\
\hline BAWSI Agricultural Workers Union of South Africa & Trade union \\
\hline Food and Allied Workers Union & Trade union \\
\hline Vinpro & Industry body \\
\hline Vinpro & Industry body \\
\hline Fairview & Industry body \\
\hline South Africa Liquor Brand Owners Association & Industry body \\
\hline Wines of South Africa & Industry body \\
\hline
\end{tabular}


Table 3: Vinmonopolet: abbreviated 8 points requirement (points 1 and 2 in relation to the BSCI code of conduct)

1. Producers and farms must take specific steps to make workers aware of their rights and responsibilities

2. Producers and farms must establish or participate in effective operational-level grievance mechanisms for workers to inform or to put forward a grievance regarding conditions

3. Producers and farms must follow up on any grievance and shall document follow up activities

4. Producers and farms shall ensure access and use of personal protective equipment

5. Producers and farms shall build competence among workers that work with pesticides.

6. Producers and farms shall ensure access to clean drinking water.

7. Producers and farms shall comply, as a minimum, with wages mandated by governments' minimum wage legislation, or industry standards approved on the basis of collective bargaining (whichever is higher).

8. Producers and farms shall respect the right of workers to form unions in a free and democratic way. 